\title{
Evaluation of Slope Assessment Systems for Predicting Landslides of Cut Slopes in Granitic and Meta-sediment Formations
}

\author{
${ }^{1}$ Suhaimi Jamaludin, ${ }^{2}$ Bujang B.K. Huat and ${ }^{2}$ Husaini Omar \\ ${ }^{1}$ Public Works Department, Malaysia \\ ${ }^{2}$ Faculty of Engineering, University Putra Malaysia
}

\begin{abstract}
In Malaysia, slope assessment systems (SAS) are widely used in assessing the instability of slope or the probability of occurrence and the likely severity of landslides. These SAS can be derived based on either one particular approach or combination of several approaches of landslide assessments and prediction. This study overviews four slope assessment systems (SAS) developed in Malaysia for predicting landslide at a large-scale assessments. They are the Slope Maintenance System (SMS), Slope Priority Ranking System (SPRS), Slope Information Management System (SIMS) and the Slope Management and Risk Tracking System (SMART). An attempt is made to evaluate the accuracy of the SAS in predicting landslides based on slope inventory data from 139 cut slopes in granitic formation and 47 cut slopes in meta-sediment formation, which are the two most common rock/soil formations found in Malaysia. Based on this study, it was found that none of existing SAS is satisfactory in predicting landslides of cut slopes in granitic formation, for various reasons such as the use of hazard score developed from another country, insufficient data base, oversimplified approach and use of data base derived from different rock/soil formations. However for the case of cut slope in meta-sediment, the Slope Management and Risk Tracking System (SMART) was found to be satisfactory with 90\% prediction accuracy. The current database of SMART is largely based on meta-sediment formation.
\end{abstract}

Key words: Landslides, cut slopes, tropical soils, slope assessment systems, granitic formation, metasediment formation

\section{INTRODUCTION}

Landslides have caused large numbers of casualties and huge economic losses in hilly and mountainous areas of the world. In tropical countries where annual rainfall can reach as high as $4500 \mathrm{~mm}$ and high temperatures around the year, cause intense weathering and formation of thick soil and weathered rock profile. With these set of climate and geological condition, combined with other causative factors, landslide is one of the most destructive natural disasters in tropical region. Malaysia is one of the countries located in the tropical region. During the period from 1993 to 2006, a number of major landslides were reported in Malaysia, involving fill and cut of natural slopes, which results in death of people.

The most common type of landslides in Malaysia is shallow slide where the slide surface is usually less than $4 \mathrm{~m}$ deep and occurs during or immediately after intense rainfall ${ }^{[1]}$. These slides commonly occur in residual soils mantles of grade $\mathrm{V}$ and grade VI according to the commonly used classification systems of Little ${ }^{[2]}$. Other types of landslides found are deepseated slides, debris flow and geologically controlled failures such as wedge failures and rock fall. Slide is defined as downward displacement or soil (or rock) sliding along one or more failure surfaces, rotational for the case of few units; translational for the case of many units ${ }^{[3]}$. Flows consist of movement of slurry of soil and loose rocks down slope in a manner analogous to a viscous fluid. Falls are incidence of masses of rocks detaching from a steep slope and descending by free fall, rolling or bouncing.

Landslide assessment for the purpose of estimating the probability of occurrence and likely severity of landslides can be carry out by various methods, namely the statistical method, landslide inventory method, heuristic approach and deterministic approach ${ }^{[4]}$. Tangestani ${ }^{[5]}$ describe attempt to use of fuzzy set theory analysis, while Yi et al. ${ }^{[6]}$ use fractal dimension, a mathematical theory that describes the quality of complex shapes of images in the nature, in evaluating landslide hazard.

In Malaysia, there are at least eight slope assessment systems (SAS) that have been developed over the last ten years. Four of these SAS, all meant for large-scale assessment, namely the Slope Maintenance System (SMS), Slope Priority Ranking System (SPRS), Slope Information Management System (SIMS) and the Slope Management and Risk Tracking System (SMART), all developed by the Public Works Department (PWD) of Malaysia ${ }^{[7-10]}$ are described in this study. Large-scale assessment refers to use of maps of scale between 1:5,000 and 1:15,000. Despite the enormous effort given to develop the slope assessment systems, no attempt has been made to date to validate 
the accuracy of any of these SAS in predicting the likelihood of landslides (slope failures). The accuracy or reliability in predicting future landslides is crucial to any SAS. Incorrect prediction will expose lives and economy to danger or hazard if a slope or an area that should has a high hazard level is incorrectly classified/predicted as with low hazard level. On other hand, if a slope or an area that should have a low hazard level is incorrectly predicted as high hazard level, it has financial implication because money will be spend to 'stabilized' the stable (not failed) slope. This research described a study that has been made to validate the existing SAS based on slope inventory data from 139 cut slopes in granitic formation and 47 cut slopes underlain by meta-sediment formations. These are the two major rock/soil formations found in Malaysia.

Granite is the major rock that underlies virtually every major mountain range with summits exceeding $2,000 \mathrm{~m}$ in Malaysia. About $30 \%(5,000 \mathrm{~km})$ of major trunk roads which involve many cut slopes, traverse through or located on hilly and mountainous areas of Malaysia. Some $75 \%$ of the roads that traversed through the hilly and mountainous areas are cut through and/or underlain by granitic formation. The remaining $25 \%$ of the roads are cut through or underlain by the meta-sediment formations (mudstone, sandstone and siltstone). These mountainous roads experienced numerous numbers of landslides occurrences in the past, usually during the wet (rainy) season from October to January, which had caused disruption to traffic, injuries and losses of life. A study carried out in the year 2000 along six selected hilly and mountainous roads shows that out of 444 landslides of various types (shallow slides, deep seated slides, debris flow and rock fall), 420 occur in cut and natural slopes ${ }^{[9]}$. The other 24 slides occur in embankment (fill) slopes.

\section{SLOPE ASSESSMENT SYSTEMS}

The Slope Maintenance System (SMS) was the first slope assessment system developed by the Public Works Department (PWD) of Malaysia, as part of the East-West Highway long-term preventive measures ${ }^{[7]}$. Statistical method using discriminant analyses based on slope type (embankment/fill and cut/natural slope) were used to determine the hazard values. The parameters captured for each slope include age of the cut slope, batter height, bench width, ratio of crest length to edge length, number of culverts, relationship between slope and topography, distance to ridge/gully, etc. From the discriminant analysis, significant slope parameters that contributed to the landslides along the highway were determined. The weightings for each parameter were then calculated using factor-overlay analysis, similar to the method proposed by Anbalagan ${ }^{[11]}$. The maximum parameters weighting of 2 was assigned to the relatively most hazardous sub-parameters. The weighting for other sub-parameters is calculated using equation (1).

Weighting $=[$ Landslides frequency for sub-parameters weighting $] \mathrm{x}$ [Maximum parameters] / [Total number of landslides] - Eq. 1
Table 1: Hazard weighting for cut slopes of main range granite used in the SMS ${ }^{[7]}$

\begin{tabular}{|c|c|c|}
\hline Parameter & Sub-parameter & Weighting \\
\hline Age in years & $<8,8-11 \&>11$ & 0 to 2.0 \\
\hline Culverts & Culvert \& No Culvert & 0 to 2.0 \\
\hline Erosion & $\begin{array}{l}\text { No erosion, Sheet, Rill } \\
\& \text { Gully }\end{array}$ & 0 to 2.0 \\
\hline $\begin{array}{l}\text { Percentage of } \\
\text { feature uncovered }\end{array}$ & 0 to 100 percent & 0 to 2.0 \\
\hline $\begin{array}{l}\text { Feature aspect in } \\
\text { degrees }\end{array}$ & 0 to 360 degrees & 0 to 2.0 \\
\hline $\begin{array}{l}\text { Rock condition } \\
\text { profile }\end{array}$ & $\begin{array}{l}\text { Claystone, } \\
\text { Conglomerate, Granite, } \\
\text { Limestone, Phylite \& } \\
\text { Sandstone }\end{array}$ & 0 to 2.0 \\
\hline
\end{tabular}

Table 2: Hazard weighting for cut slopes of meta-sediment use in the $\mathrm{SMS}^{[7]}$

\begin{tabular}{llc}
\hline Parameter & Sub-parameter & Weighting \\
\hline $\begin{array}{l}\text { Number of water courses } \\
\text { within features }\end{array}$ & \multicolumn{1}{c}{0 to 2} & 0 to 2.0 \\
Rock condition profile & $\begin{array}{l}\text { Granite, Limestone, } \\
\text { Phyllite and } \\
\text { Sandstone. } \\
\text { No Erosion, Sheet, } \\
\text { Rill \& Gully. }\end{array}$ & 0 to 2.0 \\
$\begin{array}{l}\text { Distance to ridge or } \quad \text { to }>200 . \\
\text { gully in meters }\end{array}$ & 0 to 2.0 \\
$\begin{array}{l}\text { Feature aspect in degrees } 2.0 \\
\text { Slope angle in degrees }\end{array}$ & $\begin{array}{l}0 \text { to } 360 \text { degrees } \\
0 \text { to } 90 \text { degrees }\end{array}$ & 0 to 2.0 \\
\hline
\end{tabular}

Table 3: Hazard level and range of hazard rating in percentage use in the $\mathrm{SMS}^{[7]}$

\begin{tabular}{cc} 
Hazard Score & Hazard Rating / Level \\
$80.1 \%-100 \%$ & Very High \\
$60.1 \%-80 \%$ & High \\
$40.1 \%-60 \%$ & Medium \\
$20.1 \%-40 \%$ & Low \\
$0 \%-20 \%$ & Very Low \\
\hline
\end{tabular}

For example out of 100 known landslides, 5 numbers are in the range of 8 to 11 years old slope, so the weighting for this range of age is 0.1 ( 5 divided by 100 and multiply by 2). Using this method, the weightings for other slope parameters were established. Table 1 shows example of hazard weighting for cut slopes in granitic formation as used in the SMS. The hazard weighting was developed based on 74 cut slopes (of which 31 was failed slopes) in the main range granite formation along the East-West Highway of Peninsular Malaysia.

Table 2 shows example of hazard weighting for cut slopes in meta-sediments use in the SMS. The hazard weighting was developed based on 141 cut slopes, 54 of it was failed slopes, in meta-sediment formations along the East-West Highway of Peninsular Malaysia.

Hazard score in percentage is computed by summing the parameters hazard weighting of each assessed slopes and divided by the total maximum hazard weighting. Hazard score is then converted into hazard rating or hazard level as shown in Table 3.

In 1999, the PWD developed the Slope Priority Ranking System (SPRS) as a tool for quick assessment 
of all slopes in Malaysia so that repair work can be prioritized and carried out. The SPRS is also to help identify budget requirements for slope repairs. The hazard score used in SPRS was established using very simple approach with associated ratings of 0,1 and 2, according to the definitions of each parameter given by Hussein et al. ${ }^{[8]}$. The hazard attributes for cut slope include slope angle, height of slope, slope cover, surface drain, natural water path, seepage, ponding, erosion, slope failure, surroundings upslope (human activity), soil type, weathering grade and discontinuities. Table 4 shows hazard score use for cut slopes in the SPRS.

Hazard score in percentage is computed by summing the slope attributes hazard score of each assessed slopes and divided by the total maximum hazard score. The hazard score is then converted into hazard rating as shown in Table 5.

In 2002, the Public Works Department (PWD) and the Japanese International Cooperation Agency (JICA) jointly developed the Slope Information Management System (SIMS) ${ }^{[9]}$. In this system, the slopes are assessed based on predefined likelihood of failure type that are base on definition used in Japan; i.e. slope failure/rock fall, rock mass failure, landslide, debris flow and embankment failure. The hazard score used was adopted from the Japanese experience. Parameters considered include topography, slope geometry, slope forming material, geological structure, any presence of slope deformation, surface condition and countermeasure effectiveness. Table 6 shows hazard score used for slope failure/rock fall type of failure. Table 7 shows the hazard rating applied in the SIMS.

The Slope Management and Risk Tracking Systems (SMART) is the latest slope management system developed by the Public Works Department ${ }^{[10]}$. The system is developed base on data from the Tamparuli - Sandakan road in Sabah, East Malaysia, where there have been numerous slope failures. In developing SMART, data from 918 cut slopes comprising of 741 not failed slopes and 177 failed slopes are used. This road was underlain mainly by sediment and meta-sediment formations of mudstone, sandstone and siltstone, inter-bedding each other ${ }^{[10]}$.

The system uses slope inventory forms similar to the SMS with some slight modifications. In SMART, the hazard score or instability score (IS) ranges from 0 to 1 and is derived through the integration of results from three assessment methods, that is the statistical method (stepwise discriminant function analysis converted into probability), deterministic method (factor of safety determine by Combined Hydrology and Stability Model or CHASM and then converted to probability using Monte-Carlo simulation) and if when appropriate, expert knowledge ${ }^{[10]}$. An example of a twelve-parameter regression equation (Equation 2) derived from stepwise discriminant function analysis, then converted into probability $(\mathrm{P})$, is given as:
Table 4: Hazard score used for cut slopes used in SPRS ${ }^{[8]}$

\begin{tabular}{|c|c|c|c|}
\hline Cut Slopes Hazard & & Score & \\
\hline Attributes & 0 & 1 & 2 \\
\hline i. Slope angle & $<45^{\circ}$ & $45^{0}-63^{0}$ & $>63^{0}$ \\
\hline ii. Height of slope & $<12 \mathrm{~m}$ & $12 m-24 m$ & $>24 m$ \\
\hline iii. Slope cover & $>20 \%$ & $<20 \%$ & - \\
\hline iv. Surface drains & Good & Blocked & $\begin{array}{l}\text { Repair } \\
\text { required }\end{array}$ \\
\hline v. Natural water path & No & - & Yes \\
\hline vi. Seepage & No & - & Yes \\
\hline vii. Ponding & No & Yes & - \\
\hline viii. Erosion & Slight & Moderate & Critical \\
\hline ix. Slope failure & No & - & Yes \\
\hline $\begin{array}{l}\text { x. Surroundings } \\
\text { upslope }\end{array}$ & No & - & Yes \\
\hline xi. Soil type & Gravel / sand & Silt & Clay \\
\hline xii. Weathering grade & I & II, III & IV- VI \\
\hline xiii. Discontinuities & No & - & Yes \\
\hline
\end{tabular}

Table 5: Hazard score and rating used in the SPRS ${ }^{[8]}$

\begin{tabular}{llll}
\hline \multicolumn{3}{c}{ Cut Slope } & \multicolumn{2}{c}{ Fill Slope } \\
\hline Hazard Score & Hazard & Hazard Score & Hazard Rating \\
& Rating & & \\
\hline $40 \%$ to $100 \%$ & Very High & $40 \%$ to $100 \%$ & Very High \\
$30 \%$ to $40 \%$ & High & $30 \%-40 \%$ & High \\
$19 \%$ to $30 \%$ & Moderate & $20 \%-30 \%$ & Moderate \\
$8 \%$ to $19 \%$ & Low & $10 \%-20 \%$ & Low \\
$0 \%$ to $8 \%$ & Very Low & $0 \%-10 \%$ & Very Low \\
\hline
\end{tabular}

$\mathrm{Y}=0.027$ (height $)+0.02$ (angle) +0.163 (shape) +0.354 (plan profile) +0.278 (cutting topography) +0.202 (structure) -0.172 (main cover type $)+0.472$ (cover) $+0.017(\%$ rock exposure $)-1.266$ (corestone boulders $)+0.249$ (rock condition profile) +0.281 (ground saturation) $-4.293$ - Eq. 2

Where $\mathrm{Y}$ is regression function representing 'instability score' of the assessed slopes.

For calculation of Y, the slope parameters in the bracket should be replaced by value or classes of slope variables as listed in Table 8. The equations used to transform the data from individual discriminant function scores (Y) to probabilities of group membership (i.e. failed or not failed) were derived through curve fitting. An example is shown in Table 9.

The probabilities are then grouped into groups of qualitative terms of instability category for the purpose of interpretation and action. The instability or hazard rating categories designated for this purpose are Very Low, Low, Medium, High and Very High (Table 10).

\section{FIELD STUDY SITES, SLOPES AND LANDSLIDES INVENTORIES}

Road is the main type of transportation system in Malaysia. About $30 \%$ of these roads traversed through or located in hilly and mountainous areas. These mountainous roads experience numerous landslides, which cause disruption, injuries and losses to life and economy.

Slope inventory data from 139 cut slopes in granitic formations along three different sites, namely 
Table 6: Hazard score assign for slope failure/rock fall type of failure used in the SIMS ${ }^{[9]}$

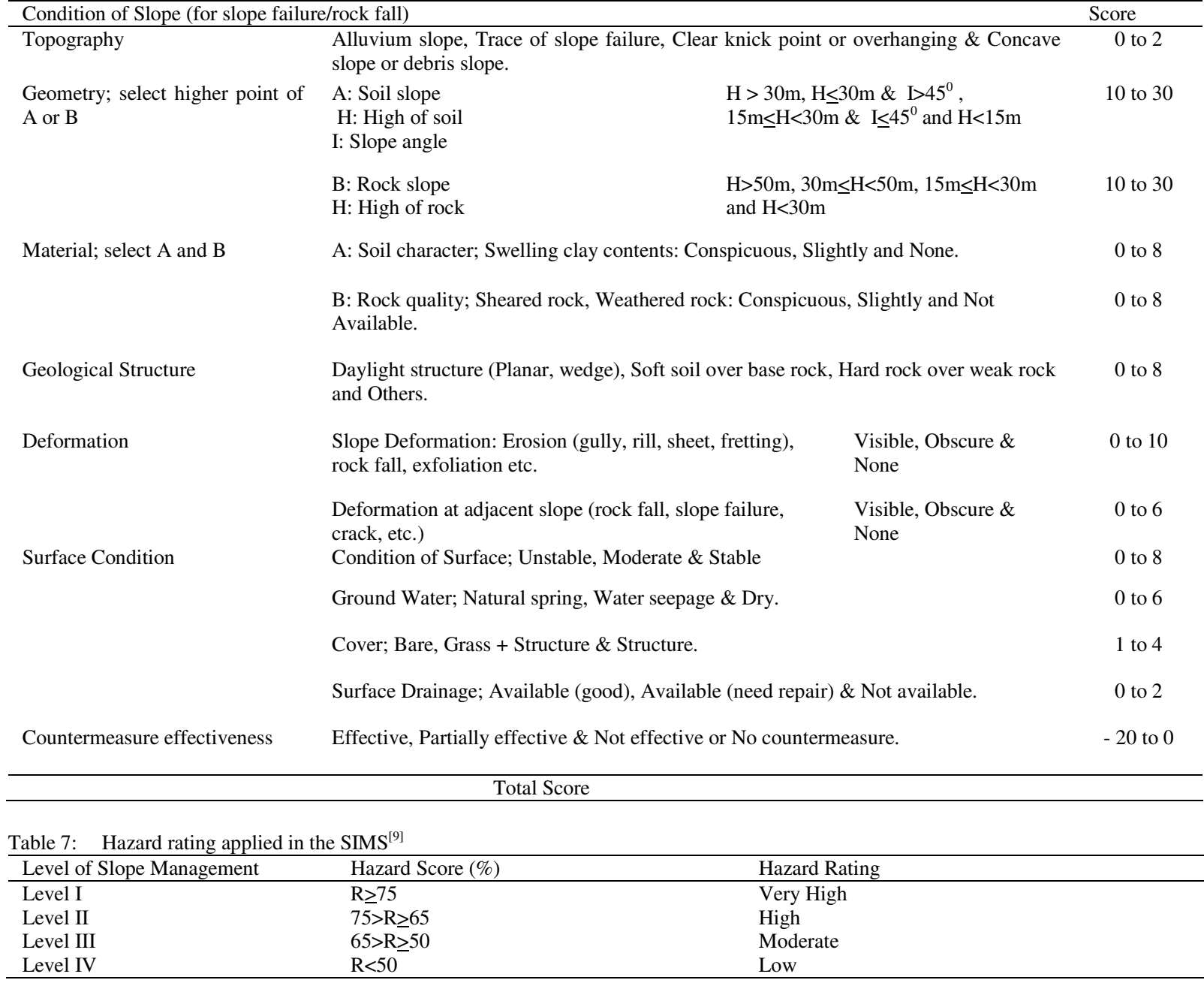

Table 8: Variables / Parameters for cut slope determined significant in $\operatorname{SMART}^{[10]}$

\begin{tabular}{cllc}
\hline No. & Slope Variable & Range of Classes & Value / Classes \\
\hline 1 & Height & Any value from 0 to 200 meters & 0 to 200 \\
2 & Slope angle & Any value from 0 to 90 degrees & 0 to 90 \\
3 & Slope shape & Simple, Planar, Asymmetrical \& Compound. & 1 to 4 \\
4 & Plan profile & Convex, Concave \& Straight & 1 to 3 \\
5 & Cutting topography & Top, Middle, Base, Basin/Flat Ground \& Sidelong Embankment & 1 to 5 \\
6 & Structure & None, Crib Wall, Piled Wall, Surface Netting, Soil Nailing, & 1 to 10 \\
& & Gabion Wall, Rock Bolts / Stitching, Concrete Wall, Masonary & 1 to 7 \\
7 & Main cover type & Wall \& Others. & 1 to 3 \\
8 & Slope cover & Grass, Shrub, Fern, Jungle, Plantation, Agricultural \& Others. & 0 to 100 \\
9 & Percentage rock exposure & Good (100\%), Average (80 to 100\%) \& Poor (< 80\%). & 0 \& -1 \\
10 & Corestone boulders & Any number from 0 to 100 \% & No \& Yes \\
11 & Rock condition profile & Majority < Grade III, Partly < Grade III \& Partly > Grade IV, & 1 to 5 \\
& & Predominantly Grade IV to Grade VI, Predominantly Grade IV to & Grade VI but with Corestone Boulders \& Predominantly \\
\hline
\end{tabular}


Table 9: Conversion of $\mathrm{Y}$ into probability, $\mathrm{P}^{[10]}$

\begin{tabular}{ll}
\hline Value of $\mathrm{Y}$ & Calculation of probability, $\mathrm{P}$ \\
\hline $\mathrm{Y}<-2$ & $\mathrm{P}=0.05$ \\
$-2<\mathrm{Y}<0.5$ & $\mathrm{P}=0.0037 \mathrm{Y}^{3}+0.0891 \mathrm{Y}^{2}+0.3195 \mathrm{Y}-0.3531$ \\
$0.5<\mathrm{Y}<4$ & $\mathrm{P}=0.0105 \mathrm{Y}^{3}-0.1275 \mathrm{Y}^{2}+0.5152 \mathrm{Y}+0.2952$ \\
$\mathrm{Y}>4$ & $\mathrm{P}=1$ \\
\hline
\end{tabular}

Table 10: Probability and instability category use in SMART ${ }^{[10]}$

\begin{tabular}{ll}
\hline Probability, P & Instability Category \\
\hline $0.0-0.2$ & Very Low \\
$0.2-0.4$ & Low \\
$0.4-0.6$ & Medium \\
$0.6-0.8$ & High \\
$0.8-1.0$ & Very High \\
\hline
\end{tabular}

the Gunung Raya road in Langkawi Island, the EastWest Highway, Perak and the Kuala Kubu Baru - Gap road, Selangor, Malaysia, were used in the evaluation of the slope assessment systems (SAS) of cut slopes in the granitic formations. Whilst data from 47 cut slopes in meta-sediment formation along the Gunung Raya road and the East-West highway were used for evaluating the SAS in the meta-sediment formation.

The slope inventory data such as slope height, slope angle, soil type, weathering grade, were collected/compiled over a ten-year period, from 1994 to 2004. These data were obtained from previous record as well as through site visits (walkthrough survey).

Landslide occurrences used were those that had occurred after the initial slope inventory data was collected. They were determined from written historical records, differences seen on multi-date aerial photos, or difference between older sketches of the data collection performa with the current site conditions. Table 11 and 12 summarize informations on the 186 numbers of cut slopes considered in this study.

Table 11: Cut slopes in granitic formation

\begin{tabular}{|c|c|c|c|c|c|}
\hline Location & $\begin{array}{l}\text { No. of cut slopes } \\
\text { considered in the } \\
\text { study }\end{array}$ & $\begin{array}{l}\text { No. of slope } \\
\text { failures }\end{array}$ & $\begin{array}{l}\text { Date of initial } \\
\text { data }\end{array}$ & $\begin{array}{l}\text { Date of slope } \\
\text { failures }\end{array}$ & $\begin{array}{l}\text { General remarks on type of slope } \\
\text { failures, reasons of failure }\end{array}$ \\
\hline $\begin{array}{lr}\begin{array}{l}\text { Gunung } \\
\text { road, }\end{array} & \text { Raya } \\
\text { Island } & \text { Langkawi }\end{array}$ & 34 & 10 & April 1996 & $\begin{array}{l}\text { Between April } \\
1996 \text { to November } \\
2003\end{array}$ & $\begin{array}{l}\text { Mostly shallow slides except one } \\
\text { deep seated slide at KM } 5.9\end{array}$ \\
\hline $\begin{array}{l}\text { East-West } \\
\text { Highway, Perak }\end{array}$ & 53 & 12 & March 1996 & $\begin{array}{l}\text { Between March } \\
1996 \text { to July } 2001\end{array}$ & Mostly shallow slides \\
\hline $\begin{array}{l}\text { Kuala Kubu Gap } \\
\text { road, Selangor }\end{array}$ & 52 & 22 & August 2000 & $\begin{array}{l}\text { Between August } \\
2000 \text { to November } \\
2003\end{array}$ & $\begin{array}{l}\text { Mostly shallow slides except } 2 \\
\text { debris flow at KM } 23.44 \text { and } \\
\text { adjacent to it }\end{array}$ \\
\hline
\end{tabular}

Table 12: Cut slopes in meta-sediment formation

\begin{tabular}{|c|c|c|c|c|c|}
\hline Location & $\begin{array}{l}\text { No. of cut slopes } \\
\text { considered in the } \\
\text { study }\end{array}$ & $\begin{array}{l}\text { No. of slope } \\
\text { failures }\end{array}$ & $\begin{array}{l}\text { Date of initial } \\
\text { data }\end{array}$ & $\begin{array}{l}\text { Date of slope } \\
\text { failures }\end{array}$ & $\begin{array}{l}\text { General remarks on type of } \\
\text { slope failures, reasons of } \\
\text { failure }\end{array}$ \\
\hline $\begin{array}{l}\text { Gunung Raya road, } \\
\text { Langkawi Island }\end{array}$ & 12 & 5 & April 1996 & $\begin{array}{l}\text { Between April } \\
1996 \text { to November } \\
2003\end{array}$ & Mostly shallow slides \\
\hline $\begin{array}{l}\text { East-West } \\
\text { Highway, Perak }\end{array}$ & 35 & 24 & March 1996 & $\begin{array}{l}\text { Between March } \\
1996 \text { to July } 2001\end{array}$ & Mostly shallow slides \\
\hline
\end{tabular}

Table 13: Accuracy of the slope assessment systems in predicting landslides

(i) Cut slopes in granitic formations

\begin{tabular}{lcccc}
\hline Prediction & SMS & SPRS & SIMS & SMART \\
\hline $\begin{array}{l}\text { (1) Number of slopes assessed } \\
\text { (2) Number of recent landslides or failed slopes }\end{array}$ & 139 & 139 & 139 & 139 \\
$\begin{array}{l}\text { (3) Number of slopes classified as High and Very High Hazard } \\
\text { that actually failed }\end{array}$ & 44 & 44 & 44 & 44 \\
$\begin{array}{l}\text { (4) Percentage of (3) compared with (2) } \\
\text { (ii) Cut slopes in meta-sediment formations }\end{array}$ & $39 \%$ & $52 \%$ & $2 \%$ & $61 \%$ \\
\hline Prediction & SMS & SPRS & SIMS & SMART \\
\hline $\begin{array}{l}\text { (1) Number of slopes assessed } \\
\text { (2) Number of actual landslides or failed slopes }\end{array}$ & 47 & 47 & 47 & 47 \\
$\begin{array}{l}\text { (3) Number of slopes classified as High and Very High Hazard } \\
\text { that actually failed }\end{array}$ & 17 & 29 & 29 & 29 \\
(4) Percentage of (3) compared with (2) & 13 & 17 & 5 & 26 \\
\end{tabular}

Note: SMS - Slope Maintenance System (SMS), SPRS - Slope Priority Ranking System, SIMS- Slope Information Management System SMART - Slope Management and Risk Tracking System. 


\section{HAZARD ASSESSMENT OF THE SLOPE AND ACCURACY EVALUATION OF THE SAS}

Accuracy or reliability in predicting future landslide is a crucial part of any slope assessment systems (SAS). In this study, the accuracy of the SAS was determined by comparing the hazard rating of each of the slopes evaluated based on the initial (earlier) slope inventory data with the later set of data, i.e. after the landslide occurrences in some cases. The accuracy in percentage was determined by comparing the number of slopes classified as high and very high hazard that actually failed with the total number of actually failed slopes.

Prior to the hazard assessment exercise, the format of the available data was transferred according to the range or classes of all SAS. Some data which was not available especially the permanent parameters related to the geometry and geological features of the assessed slope were determined through site visits (walkthrough survey). Some estimates were made for the parameter value needed in each SAS such as strength parameters of soil and rock, soil depth, permeability etc.

Table 13 summarizes the prediction accuracy of the five SAS considered in the study, for cut slopes in both granitic and meta-sediment formations.As shown in Table 13, none of the existing slope assessment systems (SAS) appeared to be satisfactory in predicting landslides in cut slopes in granitic formations. Satisfactory in this case is defined as percentage of accuracy of greater than $70 \%$ (Table 14). The reasons for this could perhaps be explained as follows.

For the case of the SMS (Slope Maintenance System), it appeared that the development of SMS using 74 cut slopes database that was limited to one site, that is the East-West Highway, was not sufficient. For the case of the SPRS (Slope Priority Ranking System), it uses a too simplified approach of assigning hazard score with only 0,1 and 2. For the case of SIMS (Slope Information Management Systems), it uses hazard score developed from other country (Japan), which appears to be its main weakness. For the case of the SMART (slope management and risk tracking systems), its current database derived mainly from the meta-sediment formations is apparently not suitable to be extrapolated to cut slopes in other rock/soil formations.

However, for case of cut slope in meta-sediment formation, SMART appears to be satisfactory with a prediction accuracy of $90 \%$, but not the other four SAS, namely the SMS, SPRS and SIMS. This is perhaps not so surprising for SMART as its current database is derived mainly from the meta-sediment formations. This seems to reinforce the earlier argument that slope assessment system develops for one rock/soil formation cannot be extrapolated to other rock/soil formation.
Table 14: Accuracy of the models from previous works by other researches on landslide assessment

\begin{tabular}{rlcl}
\hline No. & Country & Accuracy $(\%)$ & References \\
\hline 1 & Italy & $72.7 \& 80.7$ & Carrara et al. ${ }^{[12]}$ \\
2 & Italy & 72.0 & Guzzetti et al. ${ }^{[13]}$ \\
3 & Bolivia & 78 to 89 & Péloquin and Gwyn $^{[14]}$ \\
\hline
\end{tabular}

\section{CONCLUSION}

From the result of this study, it is found that none of the four slope assessment systems, namely the Slope Maintenance System (SMS), the Slope Priority Ranking System (SPRS), the Slope Information Management System (SIMS) and the Slope Management and Risk Tracking System (SMART), was satisfactory in predicting landslide in cut slopes in granitic formations, base on slope inventory data from 139 cut slopes. The reasons for this range from the use of hazard score developed from another country, to insufficient database, to the use of an oversimplified approach and to the use of database derived from different rock/soil formation.

However for the case of cut slope in metasediments, the Slope Management and Risk Tracking System (SMART) is found to be satisfactory with $90 \%$ prediction accuracy. The current database of the SMART is based on meta-sediment formation.

\section{REFERENCES}

1. Othman, M.A. and D.M. Lloyd, 2001. Slope instability problems of roads in mountainous terrain: a geotechnical perspective. Proc. Natl. Slope Seminar, Cameron Highland, Malaysia, pp: 11.

2. Little, A.L., 1969. The engineering classification of residual tropical soils. Proc. Speciality Session on the Engineering Properties of Lateritic Soil, Vol. 1, $7^{\text {th }}$ Intl. Conf. Soil Mechanics \& Foundation Engineering, Mexico City, pp: 1-10.

3. Varnes, D.J., 1978. Landslide types and processes. In Special Report 29: Landslides and Engineering Practice (E.B. Eckel, ed.), HRB, National Research Council, Washington, D.C., pp: 20-47.

4. Hussein, A.N., H. Omar and S. Jamaludin, 2004. Slope assessment and management. In Huat, BBK, Gue, S.S. and F.H. Ali, (Eds); Tropical Residual Soils Engineering, Balkema, London, pp: 103-120.

5. Tangestani, M.H., 2003. Landslide susceptibility mapping using the fuzzy gamma operation in a GIS, Kakan catchment area, Iran. Proc. Map of India Conf. GIS evelopment.net, pp: 7. 
6. Yi, S., R. Li, X. Pu and S. Fu, 2000. The fractal characteristics of the temporal and spatial distribution of the Zameila Mountain landslide activities and its fracture structure in Tibet of China. In Landslides in research, theory and practice. Thomas Telford, London. Pp: 1605-1608.

7. PWD Malaysia, 1996. Final Hazard Analysis Report. In East-West Highway Long Term Preventive Measures and Stability Study, pp: 33.

8. Hussein, A.N., K. Kassim, K.O. Lai and S. Jamaludin, 1999. A slope management system for prioritisation of cut and fill slopes in Malaysia. 10th REAAA conference: Road development for 21st Century, Tokyo, Japan, pp: 9.

9. JICA and PWD, 2002. The study on slope disaster management for federal roads in Malaysia. Final report. Vol. 1. unpublished.

10. PWD Malaysia, 2004. Slope protection study for Federal Route 22, Tamparuli-Sandakan, Sabah. Draft final report.

11. Anbalagan, R., 1995. Terrain evaluation and landslide hazard zonation for environmental regeneration and land use planning in mountainous terrain. Proc. Sixth Symposium on Landslides, Christchurch, New Zealand, pp: 861-868.
12. Carrara, A., M. Cardinali, F. Guzzetti and P. Reichenbach, 1995. GIS-Based techniques for mapping landslide hazard. In Geographical Information System in Assessing Natural Hazards. Academic Publication, Dordrecht, Netherlands.

13. Guzzetti, F., A. Carrara, M. Cardinali and P. Reichenbach, 1999. Landslide hazard evaluation: A review of current techniques and their application in a multi-scale study, Central Italy. J. Geomorphol., 31: 181-216.

14. Peloquin, S. and Q.H.J. Gwyn, 2000. Using remote sensing, GIS and artificial intelligence to evaluate landslide susceptibility levels: Application in the Bolivian Andes. Proc. of 4th Intl. Conf. on Integrating GIS and Environmental Modeling (GIS/EM4): Problems, Prospects and Research Needs. Banff, Alberta, Canada, pp: 12. 